\title{
THE CLERICAL RECEPTION OF BERNART DE VENTADORN'S 'CAN VEI LA LAUZETA MOVER' (PC 70, 34)
}

The twelfth-century troubadour Bernart de Ventadorn's song 'Can vei la lauzeta mover' is among the most famous and most anthologized of medieval love lyrics. It is held up as one of the classic expressions of the courtly poet-lover's despair of gaining his lady's favour: the strength of his desire is so great that Bernart proposes to go into exile if his lady does not show him mercy. The success of 'Can vei', at least among modern readers, is in no small part due not only to the prominent image of the falling lark with which the song opens, but also to references to Narcissus and Tristan in subsequent strophes. The song has also been the object of much scholarly attention. ${ }^{1}$ This reflects its extensive transmission in both Occitan and French-language manuscripts and the number of times Bernart's song is quoted or referenced in romances and more scholarly works such as Matfre Ermengaud's encyclopedia, the Breviari d'amor. It makes a final appearance in the long poem with lyric insertions Lo Conhort, written by the Valencian poet Francesc Ferrer around 1450. ${ }^{2}$ The debate between Bernart, Raimbaut d'Aurenga, and Chrétien de Troyes on what a love-servant can reasonably expect from his lady which grows from 'Can vei', and a probable metrical imitation by early Minnesinger Dietmar von Eist, confirm Bernart's song as the basis for a remarkably extensive poetic network crossing linguistic, generic, and formal frontiers. ${ }^{3}$

Consequently it is surprising that the metrical imitations, or contrafacta, of this song in clerical contexts in Occitan, Old French, and Catalan remain unstudied. ${ }^{4}$ The poems 'Quisquis cordis et oculi' (Analecta hymnica 2I, I685) by Philip the Chancellor of Notre Dame and what seems to be his own version in Old French, 'Le cuer se vait de l'oil pleignant' (RS 349), bear eloquent witness to the rich interactions in the grey zones between the Church and the world as well as the ease with which song moved geographically in the Middle Ages. 'Quisquis cordis' is transmitted in a large number of manuscripts with a melody recognizably that of 'Can vei', as is the Old French song in both of its witnesses. ${ }^{6}$ These two poems are joined by their Occitan contrafacta, 'Sener mil gracias ti rent' (RS 718a), and a song in the Misteri d'Elx (1350s), a devotional play performed to celebrate the Assumption of the Virgin. Together they place the relationship 
of the court and the Church in the larger context of the international movement of medieval lyric, and are an important instance of the productive interactions of these spheres.

Despite the limited interest of literary scholars in contrafacta in recent decades, with the exception of John Marshall's work, this musical-poetical practice is particularly valuable for the concrete way it allows us to trace the intellectual and artistic interactions of medieval poets, often across linguistic boundaries. ${ }^{7}$ This article thus follows a section of the European poetic network mapped out by the reception of 'Can vei' in three dimensions, motz, sos, razos ('words, melody, sense'), which reveals the afterlife of Bernart's song. It is a powerful example of the formal interactions described by Jörn Gruber:

Die einzelnen Lieder ('Vers', Canzone) sind virtuell Fragmente eines verschlüsselten Minnedialogs zwischen 'Verstehenden', die einander an gedanklicher Subtilität und formaler Virtuosität zu überbieten streben, um sich dem Ideal des summum verum, summum pulchrum und summum bonum immer weiter zu nähern. Dabei kommt es darauf an, sprachlich-metrisch-musikalische Elemente bestimmter Lieder von Vorgängern und/oder Zeitgenossen dergestalt in das neue Lied einzufügen, daß diese Lieder zugleich aufbewahrt, widerlegt und überwunden, d.h. im dreifachen Wortsinn 'aufgehoben' werden. ${ }^{8}$

(The individual songs ('vers' or cansos) are effectively splinters of a hidden dialogue on love between those who understand, who strive to outdo each other in intellectual subtlety and formal virtuosity in order to come ever closer to the ideal of the greatest truth, the greatest beauty, and the greatest good. It is thus a matter of including linguistic, metrical, and musical elements of particular songs by older and/or contemporary poets in a new song so that these songs are simultaneously preserved, denied, and exceeded, that is, are the object of Aufhebung in all three senses of the word. ${ }^{9}$ )

The practical basis of this interaction is fitting new words into the metrical form of an existing song and, by extension, allowing the use of the same melody. The melody and metrical form interact with the verbal content of the new lyrics, often, as we shall see, quite different from those original ones, creating a multidimensional artefact. As Hendrik van der Werf noted, the unusually wide reception of 'Can vei' is in no small part due to the staying power of its melody, transmitted in three manuscripts as 'Can vei' and in ten others with different words, more than any other troubadour melody. ${ }^{10} \mathrm{We}$ are consequently dealing with an exceptional case, but one which is indicative of the wider mobility and movement of vernacular song in the period. 
The mobility of medieval song brings with it the unfixity of the lyric text. The varying nature of the texts known by different audiences as 'Can vei' is a factor important for its subsequent transmission and reception. The song is best known now through the medium of Carl Appel's edition, which uses the strophic order found in MSS $Q U .{ }^{11}$ As Simon Gaunt has demonstrated, however, this text's strophic order is considerably different from that of most texts circulating in the Middle Ages, transmitted in eighteen other chansonniers. ${ }^{12}$ If the Appel version is focused on a domna who does not accept her lover's suffering as proof of his devotion, forcing him to threaten exile, the larger part of medieval audiences would probably have known a quite different 'Can vei', a song emphasizing the ill-will of the domna. Consequently, I reproduce Gaunt's text, based on troubadour MS $A$.

Qan vei la lauzeta mover de ioi sas alas contra.l rai que s'oblida e.is laissa cazer per la doussor c'al cor li vai. Ai! Tant grans enveia m'en ve de cui que veia iauzion, meravillas ai car desse lo cors de desirier no.m fon.

\section{A las! Tant cui[a]va saber} d'amor e qant petit en sai, car ieu d'amar no.m puosc tener cellei don ia pro non aurai. Tolt m'a mon cor e tolt m'a se, e mi meteus et tot lo mon, e qan si.m tolc no.m laisset re mas desirier e cor volon.

De las dompnas mi desesper: jamais en lor no.m fiarai, e aissi cum las suoil captener, enaissi las descaptenrai. Pois [vei] c'una pro no m'en te vas lieis qe.m destrui e.m cofon, totas las dopti e las mescre, car ben sai c'atretals si son.

Amors es perduda per ver et ieu non o saubi anc mai, que cil que plus en degra aver, non a ies, et on la querrai? Ai! Cum mal sembla qui la ve,
I (When I see the lark flap Its wings for joy against the sunray Who forgets itself and falls For the sweetness it has at heart

5 Oh I have because of it such great envy Of whoever I see who is joyful

I am amazed because straightaway My heart does not fail me for desire.

Alas! I thought I knew so much

Io About love, and how little I know of it For I cannot hold myself back from loving The one from whom I shall never benefit She has taken my heart away and herself And me myself and all the world

I5 And when she takes herself leaves me nothing But desire and a willing heart.

\section{I despair of ladies}

I shall never trust them because of it And as I used to respect them

20 So shall I despise them now

As I see that one does not therefore hold me Towards her and destroys me and ruins me, I suspect them all and disbelieve them For I know well the others are like this too.

25 Love is truly lost

And I have never once known it

For he who should have most of it

Never has any, and where should I seek it?

Oh! how evil she seems, whoever sees her 
e az aqest caitiu desiron, qe ia ses lieis non aura be, laisse morir, qe no.il aon.

Puois ab midonz no $\mathrm{m} \cdot$ pot valer Dieus, ni merces, ni.l dreitz q'ieu ai, ni a lieis no ven a plazer Qu il m’am, ia mais no lo dirai. E si.m part de lieis e.m recre: mort m'a e per mort li respon, e vau m'en s'ella no.m rete, caitius, en issill, no sai on.

Anc non agui de mi poder, ni non fui meus de lor en sai qe $m$ laisset de mos huoills vezer en un miraill qe mout mi plai Miraills, pois me miriei en te, m'ant mort li sospir de prion, $E$ aissi.m perdiei cum perdet se lo bels Narcisus en la fon.

D'aisso fai ben femna parer ma dompna, per q'ieu lo retrai, e ar non vol so qe deu voler, e so c’om li deveda fai.

Cazutz sui e mala merce, et ai be faich co.l fols e.l pon, e non sai per que m'esdeve, mas car poiei trop contra amon.

Tristan, non avetz ies de me, qe vau m'en marritz, no sai on, de chantar mi lais e.m recre, e de ioi d'amar m'escon.
30 And to this miserable desirer,

Who without her will never have any good, Leaves [him] to die without helping him.

Since, with my lady, neither God, nor mercy, Nor the rights I have will help me

35 And I do not come to please her; That she loves me I will never say. And so I leave her and depart She has killed me and I reply as a dead man And if she does not retain me I am going away, 40 miserable, into exile, I know not where.

I never had any power over myself

Nor was I my own from that moment on When she allowed me to see with my eyes In a mirror that much pleased me;

45 Mirror, since I saw myself in you

Sighs from the depths have killed me And so I have lost myself as lost himself Handsome Narcissus in the fountain.

Thus my lady certainly seems to be a woman, 50 as I represent her

And now she does not want what she should want, and does that which one forbids her.

I have fallen on bad mercy,

And have indeed done as did the fool on the bridge

55 and know not how I lost my way

But because I climbed too high.

Tristan you shall never hear from me

Who leaves, saddened, I know not where

I leave and give up song

60 And escape from the joy of love.)

The fact that the apparently better-known version of the text was the less courtly one, more concerned with power structures, finds expression not only in the response of other troubadours, notably the contrafacta sirventes by Peire Cardenal and Guillem Anelier de Tolosa, but also in the way in which 'Can vei' was read by its clerical recipients. ${ }^{13}$

\section{III}

Perhaps the most remarkable of these responses by churchmen are the twin pieces in Latin and Old French by Philip the Chancellor, 'Quisquis cordis et 
oculi', and 'Le cuer se vait de l'oil pleignant'. Philip was a man of considerable clerical and secular importance, and is perhaps best known for his role in the Great Dispersion, a dispute between the masters of the University of Paris and the chapter of Notre Dame between I229 and I23I regarding the Chancellor's right to award the venia legendi. ${ }^{14}$ His response to 'Can vei' is far removed from the world of courtly love, and is thus consonant with the rest of his large poetic output. ${ }^{15}$ Instead 'Quisquis cordis et oculi' is a poem which intellectualizes human passions. It has the same strophic structure as 'Can vei', 8abababab, though the second, fourth, and sixth strophes diverge slightly, with rhyme schemes $a b a b c b c b$, $a b a b b b b$, and, again, $a b a b c b c b$. Unsurprisingly there is no attempt to re-use the Occitan rhyme sounds in the Latin. ${ }^{16}$ The problems of knowledge, volition, and power which elsewhere underpin a debate on courtly convention or politics are here played out in a disputation: two cases are put and judgement is handed down. The disputants are the heart and the eye, picked out from 'Can vei' as allegorical representations of a lover's volition and perception. ${ }^{17}$ But, whereas Bernart's poem triangulates between the eyes and heart of the lover and the domna's eyes, whether we read them as the mirror of the lover's desire or not, the dispute here is wholly internal.

Quisquis cordis et oculi non sentit in se iurgia, non novit qui sint stimuli, quae culpae seminaria, causam nescit periculi, cur alternent convicia, cur procaces et aemuli replicent in se vitia.

Cor sic affatur oculum: 'te peccati principium, te fomitem, te stimulum, te voco mortis nuntium; tu, domus meae ianitor, hosti non claudis ostium, familiaris proditor admittis adversarium.

'Nonne fenestra diceris, qua mors intrat ad animam? Nonne quod vides sequeris ut bos ductus ad victimam? Cur non saltem, quas ingeris, sordes lavas per lacrimam? Aut quare non erueris mentem fermentans azymam?'
I (Whoever does not feel in himself The quarrels of the heart and eye

Does not know what the spurs might be,

What the seeds of blame,

5 Does not know the cause of the case,

Nor why they [heart and eyes] exchange abuse

Why the unruly enemies

Might exchange offences among themselves.

The heart addresses the eye thus:

IO 'You the origin of sin

You kindling, you spur,

I call you the messenger of death;

You, gatekeeper to my house,

Do not close the gate on my enemy:

I5 Household traitor,

You admit the enemy.

'Are you not called "window"

Through which death enters the soul?

Do you not follow what you see,

20 Like the ox led to the slaughter?

Why do you not even wash with tears

The filth you let in?

Or else why are you not destroyed

Who make sinful the sinless mind?' 
Cordi respondet oculus; 'iniuste de me quereris, servus sum tibi sedulus, exsequor quidquid iusseris; nonne tu mihi praecipis sicut et membris ceteris? Non ego, tu te decipis: nuntius sum, quo miseris.

'Cur damnatur apertio corpori necessaria sine cuius obsequio cuncta languent officia? Si quae fiat irreptio, cum sim fenestra vitrea, si, quod recepi, nuntio, quae putatur iniuria?

'Addo, quod nullo pulvere quem immittam pollueris, nullum malum te laedere potest, nisi consenseris. De corde mala prodeunt, nihil invitum pateris; virtutes non intereunt, nisi culpam commiseris.'

Dum sic uterque disputat soluto pacis osculo, ratio litem amputat definitivo calculo; reum utrumque reputat, sed non pari periculo, nam cordi causam imputat, occasionem oculo.
25 The eye replies to the heart:

'You attack me unfairly

I am your diligent servant

I carry out your every order.

Do you not give me orders,

30 As to the other body parts?

Not I, but you lead you astray:

I am a messenger, where you send me.

"Why is the opening, necessary

To the body, damned,

35 Without whose service

All functions would be idle?

If there is to be a sally port,

Although I am a glazed window,

If I announce what I have received,

40 Why is this thought to be unjust?

'I'll go further, because you whom I shall send are polluted with no dust,

Nothing evil can harm you

Unless you consent to it.

45 Evil things spread from the heart

You suffer nothing unwillingly.

Virtues do not enter in

Unless you have committed an error.'

So they both argue until

50 It is resolved with a kiss of peace,

Reason ends the dispute

With a final judgement;

He indicts both defendants,

But not for the same reason,

55 For he holds the heart responsible for the cause, and the eyes for the opportunity.)

The transformation into a disputation is accompanied by legal vocabulary ('periculum' line 5, 'replicere' line 8) laying bare the implicitly contractual side of love service, merely metaphorical in 'Can vei'. Philip strips away the layers of metaphor and reduces emotions to the basics, a stark contrast with the more veiled aesthetic of his courtly inspiration. This critical process is made all the more striking for the audience by the presence of that first song's melody. The plaintiff and defendant present their cases, using metaphor to explain and reveal rather than obscure. And yet the heart finds six different ways of describing the eye's role as 'peccati principium' (line Io) ('origin of sin'), portraying it as a traitor who admits sin to the body. ${ }^{19}$ Such repetition anchors the piece in the 
courtroom and the pulpit. The heart's case is weakened by the change in tone between the second and third strophes, from initial accusations of being an active traitor with active verbs to being faulted for its passivity. The eye merely admits sin like a window (compare the passives diceris, ingeris, and deponent sequeris). The image of the cow led to the slaughter in particular jars with the heart's argument: 'bos ductus ad victimam' is not simply complacent, but more a means of expiation than a way into sin. The heart's imagery backfires, however, in the intellectual atmosphere of the early thirteenth century, influenced by the earlier thought of Peter Abelard, discussed below, when sin was held to depend on the sinner's consent: cattle, unthinking, cannot sin. However, if the heart's speech is a deliberate echo of Proverbs vii, a warning against adultery, this negative reading of the bull to the slaughter (Prov. vii.22 is the only comparable biblical phrase) is less surprising. Philip has tailored the song to an audience simultaneously well versed in Scripture and in courtly love, as without knowledge of the biblical passage the joke falls flat:

2 serva mandata mea et vives et legem meam quasi pupillam oculi tui

3 liga eam in digitis tuis scribe illam in tabulis cordis tui

2 (Keep my commandments, and live; and my law as the apple of thine eye.

3 Bind them upon thy fingers, write them upon the table of thine heart)

Fenestra, through which the onlooker perceives sin, comes from Prov. vii.6, where a young man at a window gives in to adulterous temptation, the same misdeed of which the heart accuses the eye. By contrast, the eye's speech is imbued with the vocabulary of rewarding service. It is not merely 'servus sedulus' (line 27), but does what the heart orders (line 28), and sees itself as one 'sine cuius obsequio / cuncta languent officia' (lines $35 \mathrm{f}$.). All of this can be read as an elaborate reprise by Philip of the fundamental dependence of the courtly lady on her poet-lover. Without the poet, or the eyes perception, there is no domna. Indeed, Philip himself seems to be making an apologia for the very act of re-using secular love songs, equivalent to the eye's admission of that which is sinful, responding to the notion that this was an improper subject for a man of his situation. ${ }^{20}$

However, Philip's ethical concerns are by no means purely secular. The question implicit in his poem is: where does sin begin? As noted, his response is coloured by Abelard's conviction that consenting to sin is the point at which sin is committed. ${ }^{21}$ 'A man could not be called a sinner because he did what was objectively wrong, nor because he felt a sinful desire; sin, purely and simply, lay in consent to sinful desire. ${ }^{\prime 22}$ This is the main plank of the eye's defence, and it is hammered home:

Nullum malum te laedere potest, nisi consenseris, 
De corde mala prodeunt,

nihil invitum pateris

The heart, seat of volition, is at fault, or so it seems from the driving rhetoric of these lines, always moving toward the grammatical subject, the target of the eye's critique. In the allegory Ratio resolves the dispute: the parties exchange the legally and liturgically loaded osculum pacis. After the powerful rhetoric of the two cases, the conclusion seems rather weak.

reum utrumque reputat

52

sed non pari periculo

nam cordi causam imputat

occasionem oculo.

The extent to which the 'Latin' audience for this lyric shapes it is revealed by comparison with Philip's own Old French version of 'Quisquis cordis et oculi'. 'Le cuer se vait de l'oïl pleignant' (RS 349) is the only French lyric attributed to Philip the Chancellor, although the dit composed on his death at Christmas I236 by Henri d'Andeli suggests there were others. ${ }^{23}$ Philip conserves the melody of 'Can vei', but changes the rhyme scheme from Bernart's octosyllabic ababcdcd to $a b a b a b a b$, that is, the prevailing form of the Latin lyric. The melody, however, remains the same, and there is no reason to see a hierarchy in the two songs. ${ }^{24}$ ' $\mathrm{Le}$ cuer se vait' shifts the terms of debate to a less bookish mode, away from biblical imitation, but is no less serious. What in Latin was a scholastic disputation with judgement is here an open-ended argument.

Le cuer se vait de l'oil pleignant et dit qu'il a fet mesprison, qui doit estre son bien voillant; si ne li mostre se mal non.

Alement le vet decevant et fet vers li comme felon et comme fel et souduiant; si l'en rete de traïson.

'Tu es portier de ma maison,' fet li cuer, 'la nuit et le jor; mes tu me sers con mauvez hon, qui est traitres vers son seignor. Tu es pire que Guenelon, tu es mon privé traïtor; quar quant je sui en garnison, mes anemis mes en ma tor.

'Par toi vient la mort et apoint, tu me sers toz jors a rebors;
I The heart is complaining about the eye

And says it has done him wrong,

Which should be his well-wisher;

[Instead] it shows nothing to him but ill will.

5 It constantly deceives him

And behaves like a criminal

And like a felon and mercenary;

Thus he accuses him of treason.

'You are the gatekeeper of my house,'

Io Says the heart, 'night and day;

But you serve like a wicked man

Who is a traitor to his lord.

You are worse than Ganelon,

You are my intimate traitor;

I5 For when I am in my stronghold,

You let my enemies into my tower.

'Through you, death comes and stabs [me], You serve entirely contrary to my wishes; 
tu es l'aguillon, qui me point ausi come l'on bete l'ors.

Tu ne me sers de riens a point; je n'avrai ja par toi secors.

Foux sui, se j'en toi me fi point; de toi me sont tuit li mal sors.

'Par toi conmence tot pechié; tu es messagier de la mort. Par toi sui de mal entechié; tu es celui qui point et mort. Tu es qui en pechié m'amort; par toi sui toz jors entechié. Par ta fenestre s'est fichié en moi le pechié qui m’a mort.'

'Mout m'as traveillié et maté,' fet li oil au cuer, 'malement; souvent sui par toi enhané. A tort fes tel conplaignement. Con ton message sui mené, je fais tot ton conmandement. Tu ne dis pas comme sené; de la traïson te desment.

'Ton serjant sui preus et legier; quant que je voi te fas savoir. Se por ce entres en pechier, ne m'en dois nul maugré savoir; car bien as oï afichier et encor le dit on, par voir, que ne doivent li messagier ne bien oïr ne mal avoir.

'Quant a toi en message vien, Je te nons quanque j'ai veü. Se bien te senble, se.l retien; Ja de mal ne soiez meü. Se prens le mal et les le bien, Desque tu le t'es eslueü; A moi, qu'en apartient de rien? Tu meïsmes t'es deceü.'
You are the needle that jabs me,

20 As one baits a bear.

You do not serve me properly in any way;

You will never give me succour.

I am mad if I trust you at all;

All my ills have come from you.

25 'All sin begins with you;

You are Death's messenger.

Through you, I am infused with wickedness;

You are the one who stabs and kills.

You are the one who conditions me to sin;

30 Through you I am ever stained.

Through your window the sin which has killed me Has taken root in me.'

'You have belaboured and checkmated me,'

Says the eye to the heart, 'in an evil way;

35 I am often harassed by you.

You are wrong to complain so.

I am sent out as your messenger,

I do all your bidding.

You do not speak any sense;

40 You are mad with treason.

'I am your fleet-footed and noble sergeant;

Whatever I see, I let you know.

If you commit sin because of that,

You should not blame me;

45 For I have certainly heard,

And, in fact, it is still said,

That messengers ought not

To hear praise or be ill-treated.

'When I bring a message to you,

so I tell you whatever I have seen.

If it seems good to you, take it to heart;

Never be moved by evil.

If you take the evil and leave the good,

Once you have selected it;

55 What has it got to do with me?

You have deceived yourself.'

In place of the biblical echoes in the heart's complaint we find a reference to Guenelon, the traitor of the Chanson de Roland (line 13) embodying the eye's faithlessness. This is part of a general militarization in the vernacular poem, clearly influenced by the classical tradition of psychomachia. Thus the Latin 'admittis adversarium' (line I6) becomes 'quar quant je sui en garnison / mes 
anemis mes en ma tor' (lines Iff.) ('For when I am in my fortress, you let my enemies into my tower').

The rhyme words of the third and fourth strophes emphasize this forcefulness, both in meaning and rhetoric. The heart's argument progresses from the fourfold repetition of 'point' in lines $17,19,21$, and 23, punning on the plural senses of the word: pricking, the negligibility of the heart's trust in the eye, service 'de riens a point', ${ }^{25}$ all negative, all bound together in the one word. By contrast, the heart's peroration begins 'Par toi commence tot pechié' (line 25), a fairly neutral rendering of 'te peccati principium'. With 'pechie' in the privileged rhyme position, sin is omnipresent. Thus, when death appears at the end of the following line, the two together contrast with the relative subtlety of the Latin.

Just as these two songs show the Chancellor stripping down human emotion and activity to their basics, he also parallels the troubadours' desire to reveal the mechanics of their poetry. He thus follows the same critical path as Raimbaut d'Aurenga and Chrétien de Troyes in their responses to Bernart's philosophy of love in 'Can vei' (devotion and the lover's expected reward), which hint at the ill-concealed political and social climbing seen in love service by critics such as Erich Köhler. ${ }^{26}$ Philip underscores the fundamental sinfulness behind human emotions, and the actor's responsibility for his actions. This comes to the fore in the vernacular song's ending, which lacks the explicit resolution of 'Quisquis'. Instead the audience must reach its own conclusion, and this makes the piece particularly powerful. The eye's response to the heart is as close to the Latin as was the first section: the eye declares that it is merely doing its duty as 'serjant':

quant que je voi te fas savoir $\quad 42$

Se por ce entres en pechier,

ne m'en dois nul maugré savoir.

The eye points here, for the first time, to knowledge, the underlying source of both potential power and sin. The heart has chosen to act sinfully. In this sense the Old French song differs intellectually from the Latin: where 'Quisquis' emphasizes Abelardian consent to sin, the vernacular posits sin as something that is done, not merely accepted:

Se bien te senble, se.l retien; $\quad 5$ I ja de mal ne soiez meü.

Se prend le mal et les le bien, desque tu le t'es esleü;

a moi, qu'en apartient de rien?

Tu meïsmes t'es deceü.

Without the boundary of Ratio's judgement, the eye's response reaches out to the audience, like a preacher leaning over his pulpit to make his peroration.

If we consider 'Quisquis' and 'Le cuer se vait' as Philip sitting in judgement 
on 'Can vei', his point of departure, he appears to side with Bernart, aligned with the meek fenestra, who just does his job - and thereby justifies his own poetic activity. Philip thus remains, despite the remarkable twist he puts on the material of 'Can vei', an unlikely ally of courtly poets, whose sight and communication are of prime importance, while volition and sin are the 'causa periculi' in the sense of 'the reason for the trial'. Ultimately, it is the mediating activity of poet and, perhaps, by implicit analogy, the priest, that is the engine for his songs. By elaborating this to the melody of a well-known canso, Philip takes full cognizance of the melody's baggage before turning it on its head, much as did Johan Esteve when he composed a planh or dirge to the melody of 'Can vei'. ${ }^{27}$ Philip the Chancellor thus effectively combines the song's variant readings arising from the two opposed manuscript traditions, the despairing lover of $Q U$ and the more cynical and misogynistic interpretation encouraged by MSS $A G L P S$. Indeed the informed member of his audience would remember that in the Bible the adulterous lover is led 'ut bos ad victimam', and understand that Philip, in using the melody of 'Can vei', is elegantly demonstrating his critique of courtly love, using the connotations of Bernart's melody to full ironic effect. Not only would the melody's fame benefit Philip practically, it allows him to create a nuanced, 'three-dimensional' response to the troubadour tradition from his position in the Church.

The existence of twin lyrics like these deserves comment as a rare instance of a poet translating his own lyrics. The simplest interpretation is that Philip wished to accommodate two separate audiences divided by linguistic competence, but not by intelligence: the vernacular lyric, while not a disputation, is no less sophisticated. It is not for a 'lesser' audience, requiring as it does advanced understanding of ethics, nor is it compatible with Philip's ecclesiastical and social position that he would write for a broader public. Ultimately, this choice appears to be about decorum: it is only fitting to comment on courtly love, an essentially vernacular phenomenon, in the vernacular itself.

\section{IV}

The reception of Bernart's love lyric in religious contexts is not, however, restricted to the north, and the melody of 'Can vei' also appears in the Occitan Jeu de Sainte Agnes, a devotional play that comes down in the unique fourteenth-century MS Biblioteca Apostolica Vaticana, Chigi C.V.Isi. The play tells the story, following the Gesta Sanctae Agnetis of Pseudo-Ambrose, of the young Christian who, refusing marriage to the son of the Roman governor, is sent to a brothel, but refuses to recant, and is consequently martyred. ${ }^{28}$ 'Sener mil gracias te rent', the hymn of gratitude sung to God by the eponymous heroine for clothing her when she is naked in the brothel, is preceded by the rubric: 'et Aines induit 
indumentum quod misit ei dominus, et postea facit planctum in sonu SI QIS CORDIS ET OCULI' (after line 474) ('And Agnes puts on the clothes which the Lord sent her, and then sings a lament to the melody of " $\mathrm{Si} \mathrm{q}[\mathrm{u}]$ is cordis et oculi"). ${ }^{29}$ The notation records a version of the melody which accompanies 'Can vei' in Occitan MSS GR. It exhibits few departures, the most major of which is a simple three-note cadence at the end of the strophe in the place of $G R$ 's elaborate melisma. ${ }^{3 \circ}$ The single strophe of 'Sener, mil gracias ti rent' clearly echoes Bernart's meditations on the duties of the feudal lord, projected onto God: 'Can vei' is still spectrally present in both text and, more importantly for the audience, melody.

Sener, mil gracias ti rent qar non mi voles desnembrar qe nuda era infr'esta gent ar sui vestida d'un drap car Aytal senor tan conoisent deu hom servir et asorar qes als sieus el non es fallent als obs, anz lur vol ajudar.

\section{(Lord, I give you a thousand thanks} For you did not want to forget me Who was naked among these people: Now I am clothed in rich cloth Such a merciful lord, 480 one must serve and adore him, for he does not fail his own in their need, rather he wishes to help them.)

The second half of the strophe in particular reveals the spectral presence of the underlying concern of Bernart's song. ${ }^{31}$ It thus bears a clear similarity to 'D'Amors qui m'a tolu a moi' (RS I664), Chrétien de Troyes's response to Bernart's philosophy of love service. Chrétien says of love that 'as siens ne puet ele faillir' (line 13) ('she cannot fail her own'). More likely, though equally conjectural, is that the Agnès author was influenced by the memory of the political-feudal use of the melody of 'Can vei' in the sirventes by Peire Cardenal and Guillem Anelier de Tolosa. ${ }^{32}$ Indeed this interpretation is supported by the knowledge of the wider troubadour corpus evident in the rest of the play: the Jeu also includes contrafacta of songs by Guilhem IX (also signalled in the rubric) and Giraut Borneil. The fact that the 'original' text is declared in the rubric, even if the incipit is confused, means that this song is a quite conscious contrafactum and at least some of its recipients can be expected to have appreciated the spectral resonances of the 'original' Latin. The rubric, however, raises the question of what counts as the 'original' song for the audience, who could not have known the whole of the extensive afterlife of 'Can vei'. Does it matter that the compiler of the Chigi manuscript appears not to know that Philip's song is itself a contrafactum? Attribution of origins to Philip could connote the loss in transmission of Bernart's authoritative stamp, and yet melodic identity lives on here. As Elisabeth Schulze-Busacker has noted, the play can perhaps be traced to Béziers in view of the town's long pedigree as a centre for the cult of St Agnes, combined with Jeanroy's localization of the language of the manuscript to the coast of the south-western Midi. ${ }^{33}$ She further notes the high correlation 
of melodies used as bases for contrafacta in the play with quotations in Matfre Ermengaud's Breviari d'amor. Since Matfre, a native of Béziers, quotes 'Can vei', it is possible the Agnes author did in fact know the courtly origins of the melody. Consequently, attribution to the more recent Latin text can be understood as a dissimulation of the melody's less than religious origins, an option not available in the cases of the other troubadour melodies. This interpretation, however, troubles both Schulze-Busacker's interpretation of the play and, later, that of Nadine Henrard, as a religiously coded celebration of troubadour traditions after the Albigensian crusade. ${ }^{34}$ The Agnes play's author is, it seems, not an unqualified supporter of the troubadours, and his work requires more nuanced consideration.

The three songs discussed so far were thus performed to the same melody, and 'Sener, mil gracias ti rent', contrafactum of a contrafactum, gives a melody which is very largely the same as that of the first lyric. At least it was sung to this melody by some; this caveat is necessary in light of a passage in the chronicle of the Franciscan friar Salimbene, active in late thirteenth-century Parma. He declares that his tutor, Henry of Pisa, set Philip's 'Quisquis cordis et oculi' to original music, as well as a number of his other lyrics. The passage is valuable for the light he shines on the musical setting of lyrics, who did it, and how it was done.

Item [sc. Henry] cantum fecit in illa littera magistri Phylippi cancelarii Parisiensis, scilicet:

\section{Homo quam sit pure}

mibi de te cura.

Et quia cum esset custos in conventu Senensi in infirmatorio iaceret infirmo in lecto et notare non posset, vocavit me et fui primus qui eo cantante notavi illum cantum. Item in illa alia littera, que est cancellarii similiter cantum fecit, scilicet:

Crux de te volo conqueri;

Virgo, tibi respondeo;

Centrum capit circulus;

Quisquis cordis et oculi.35

(He sang a song with the words of Master Philip, the Chancellor of Paris, that is:

However pure a man might be, look after me.

And indeed when he was warden, and was lying ill in bed in the infirmary of the house at Sienna and could not write notation, he called for me and I was the first, from his singing, to notate that song. He composed a melody for other words, also by the Chancellor, that is:

Cross, I wish to be conquered by you;

Virgin, I answer you;

The circle takes the centre

Whoever [sc. does not know the struggles] of the heart and eye.)

As noted, Jeanroy locates the unique manuscript to the coast of south-western Provence. Beyond this the lyrics, if not the original melody, were evidently known in Tuscany. ${ }^{36}$ That the melody of 'Can vei' was transmitted north from 
the southern courts to Paris then back south by clerical channels underlines its remarkably far reach and effectiveness in both secular and clerical spheres, and the mobility of lyric culture in medieval Europe it represents. The Agnes play is thus not merely another example of the fundamental problems facing histories of artistic reception, that is, the potential loss of meaning in transmission, and the difficulty of knowing what was known of predecessors at each stage of the process, it is also an important instance of how these artefacts can cross the grey zones between geographical and social contexts, demonstrating a flexible and pragmatic attitude to secular music in clerical circles.

By contrast, the Assumption Play of Elche in Valencia is explicit about its re-use of what it thinks of as Bernart's melody. The play is first mentioned in a document dated 1492, though this claims the play to be a translated version of one recorded in $1353 .{ }^{37}$ As in the Agnes play, the rubric of the misteri declares the deliberate contrafacture at work here:

E responguen tantost les donzelles: 'Senyora, tot nostre voler', al so de Quant vey la lauseta mover. E aprés, vagen les donzelles al poble. E diguen los poble de deu. $\mathrm{E}$ lo poble los respon, atots es cert. E puys diguen los les dones / e donzelles. E apres vaga lo poble a la Maria e entren p(er) la porta e facen sa reverenca besant la ma / e digue(n) lur cobla, apres diguen dones / donzelles. ${ }^{38}$

(And the maidens respond straightaway, 'Madam, all our willing', to the tune of Quant vey la lauseta mover. And afterwards the maidens go to the people. And they tell the people of God. And the people reply, 'That is certain.' And then the ladies and the maidens say that to them. And afterwards the people go to Mary and enter through the door and reverence her, kiss her hand and say their song, after which the ladies and maidens say theirs.)

While this incipit hints at the preservation of rhyme sounds in the Assumption play, the text is unrecorded. The manuscript (late fourteenth or early fifteenth century), which appears to be that of the actor playing the Virgin, includes clear Occitan traits ('maire' for 'mare'<MATER), and differs markedly from the 'Consueta', a group of manuscripts recording the play in its modern form, of which the earliest is dated $\mathrm{I} 625$, but which transmit music probably from the later sixteenth century. ${ }^{39}$ The play's significance as an instance of the transmission of courtly melodies in a context far from their origins was first recognized by Jaume Massó i Torrents:

aquests sons retrets no podien ésser altra cosa que unes cançons de bressol i aires populars amorosos en la ignorància que algunes d'elles eren d'autors prou coneguts. Aquests podien però haver-se un xic popularitzat fins al punt de retreure'n tonades per ésser cantats els versos que s'hi apliquen..$^{40}$

(these reported melodies cannot be anything else but cradle-songs and popular romantic lyrics, not knowing that some of them were by rather well-known authors. 
These songs could, however, have a measure of popularity so that their melodies would be used with the words that fit them here.)

The choice in the earlier version of the Misteri of Bernart's melody is fully conscious and it comes at a moment of particular importance in both the drama and the events the play represents, following as it does lines sung by the Virgin presaging her Assumption:

\author{
Donzelles, fels anats tost prestame(n)t \\ E fayts venir del poble moltan gent \\ Car yols vull dar la benediccio \\ Ans que yo pas desta vida present \\ E puys veuran maravellosament \\ Ab gran repaus la mia assumpsio
}

\begin{abstract}
(Damsels, faithfully go straight away And make many of the people come For I want to give them a blessing Before I pass from this present life And then they shall see with wonder My Assumption with great relief.)
\end{abstract}

The composer or writer of the play has thus chosen the most famous song possible for this most auspicious moment, and it is remarkable that he chooses a worldly song. It is perhaps for this reason that Bernart's is the only 'so', or melody, to be mentioned by name in the manuscript - other songs are recorded with phrases such as 'en lo sobredit so' ('to the abovementioned melody'). This fact betrays the song's particular prominence in the ears of the writer of this record of the play, and bears witness to its relatively widespread presence along the Mediterranean coast.

The two clerical plays' practice of contrafacture records the adoption of worldly songs to garner the interest of a secular audience, and it is notable that in both instances the melody comes at a point of particular narrative and, by extension, theological importance. As such we can see the lining up of the secular canon with the religious contents of the play, with the most important part of the play being marked with the best-known melody, a variety of warning signal for the audience. More specifically, the particular moments with which the melody is associated, the Assumption of the Virgin, perhaps an echo of Bernart's threatened exile, and St Agnes's gratitude, channelling the thought given to the correct reward for a devoted (love) servant, seem to retain some of the inflections of 'Can vei' as described above. They are thus yet further evidence of the role of the 'so', the melody, in carrying 'Can vei' far beyond the boundaries of Occitania. The explicitness with which both 'Senor mil gracias' and 'Senyora, tot nostre voler' present themselves, or are recorded, as contrafacta of 'Quisquis' and 'Can vei', reinforces the celebrity of Bernart's song in the Middle Ages. The mystery plays thus stand in mediated dialogue with the troubadours, partly through the medium of Philip's perceptive dissection of the ethics of courtly love.

The variety of these responses to Bernart's song and, indeed, later reactions to those responses shows that a musical and poetic network is not merely a question of geographical or even linguistic distance, but can also be one of 
changing social contexts. Further, it demonstrates how contrafacta, like variant manuscript texts, hold encoded in them certain understandings of a lyric which may not survive elsewhere and in more conventional records. The practice of re-using secular melodies allowed clerical poets to create more richly resonant artefacts by gesturing to the simultaneous omnipresence of the courtly in the divine, and, more importantly in this case, the presence of the relationship with God in supposedly profane pieces. They thus bear witness to the range of fruitful and meaningful uses to which a well-known melody could be put. 'Can vei', then, was not only highly successful on its own terms, but it benefited from and contributed to the permeability of the profane-sacred boundary, and encourages further scholarship across linguistic and disciplinary frontiers in order better to illuminate the sometimes hidden interconnections of medieval culture.

Université Paris Ouest

DAVID MURRAY

\section{NOTES}

I would like to thank Simon Gaunt and Brianne Dolce for their comments on earlier drafts of this piece, and also Anna Alberni and Simone Ventura for their help in translating the Catalan passages quoted.

${ }^{1}$ See for example Erich Köhler, 'Zur Struktur der altprovenzalischen Kanzone', Cahiers de civilisation médiévale, 7 (1964), 40-51; Frederick Goldin, The Mirror of Narcissus in the Courtly Love Lyric (Ithaca, NY, 1967), pp. 96-IoI; Leslie Topsfield, Troubadours and Love (Cambridge, 1975), pp. I28-31; Sarah Kay, 'Love in a mirror: an aspect of the imagery of Bernart de Ventadorn', ME, 52 (1982), 272-85; and Michael Kaehne, Studien zur Dichtung Bernarts von Ventadorn: Ein Beitrag zur Untersuchung der Entstehung und zur Interpretation der höfischen Lyrik des Mittelalters, Freiburger Schriften zur romanischen Philologie 40/I-2, 2 vols (Munich, I983), II, 235-52.

2 There is no study devoted to the quotations of 'Can vei'; on some of the quotations in Old French romance, see Kay, 'La Seconde Main et les secondes langues dans la France médiévale', in Translations médiévales: cinq siècles de traduction en français au Moyen Âge (XIe-XVe siècles): étude et répertoire, ed. Claudio Galderisi, 3 vols (Turnhout, 20II), I, De la 'translatio studii' à l'étude de la 'translatio', pp. 46I-85. On Ferrer see Martí de Riquer, Història de la literatura catalana. Part antiga, 5th edn (Barcelona, 1993), III, 4I7-2I. Text: Lo Conhort de Francesc Ferrer, ed. Jaume Auferil (Barcelona, 1987).

${ }^{3}$ On the 'Carestia' debate between Bernart, Raimbaut, and Chrétien, see most recently Luciano Rossi, 'Carestia, Tristan, les troubadours et le modèle de saint Paul: encore sur "D’Amors qui m'a tolu a moi" (RS I664)', in Convergences médiévales: épopée, lyrique, roman: mélanges offerts à Madeleine Tyssens, ed. Nadine Henrard et al., Bibliothèque du Moyen-Âge I9 (Brussels, 200I), pp. 403-19. The present study focuses on Bernart's clerical reception: there also exist three contrafacta by troubadours (the sirventes by Peire Cardenal, 'Tostemps vir cuidar en saber' (PC 335, 58); Guillem Anelier de Tolosa, 'Ara farai, no·m puesc tenér' (PC 204, I), and a planh by Johan Esteve, 'Planhen ploran ab desplazer' (PC 266, Io)), as well as a number of Old French ones. For the French lyrics, see Hans Tischler, 
Trouvère Lyrics with Melodies: Complete Comparative Edition, I5 vols, Corpus mensurabilis musicae 107 (Neuenhausen, 1997), III, no. 203. Dietmar von Eist's 'Der winter waere mir' is in Des Minnesangs Frühling, ed. Karl Lachmann and Moriz Haupt, 36th edn by Hugo Moser and Helmut Tervooren, 2 vols (Stuttgart, I977), I, no. 35, I5.

4 This is especially surprising as much of the reception of 'Can vei' was collected by Anna Ferrari in her Vita e fortuna d'un testo lirico provenzale: Bernart de Ventadorn, 'Can vei la lauzeta mover' (BdT 70, 43): materiali di lavoro seminariale (Rome, 1988).

5 Analecta hymnica medii aevi, ed. Clemens Blume and Guido-Maria Dreves, 55 vols (Leipzig, 1886-1922). Hereafter $A H$. References are to volume and song number.

${ }^{6}$ Cf. the Paris MSS $P$ BnF fr. 847, fol. I8I and $X$ n.a. fr. I050, fol. I9I. The witnesses of the Latin conductus: Cambridge, Corpus Christi College, MS 48I, fol. 382; Cambridge, UL, Dd. II. 78, fol. II9 ${ }^{\mathrm{r}}$; Cambridge, UL, Ee. 6. 29, fol. II ${ }^{\mathrm{r}}$; Florence, Bibl. Laur, Plut 29, I, fol. $437^{\mathrm{v}}$ (mel); London, BL, Egerton MS 274, fols $24^{\mathrm{v}}-25^{\mathrm{r}}(\mathrm{mel})$; London, BL, Cotton MS Julius D.xi, fol. 99 ${ }^{\mathrm{v}}$; London, BL, Harley MS 978, fol. 88 ; London, Lambeth Palace Library, MS II4, fol. $32^{\text {b}}$; Madrid, BN, MS ${ }_{2} \mathrm{~N}_{4}$; Munich, Bayerische Staatsbibl., Clm I4343, fol. I55; Paris, BnF, lat. 37I8, fol. II; Paris, BnF, lat. 8207 (fol. unknown); Paris, BnF, lat. 8433, fol. 46 (mel); Paris, BnF, lat. 11867 , fol. 239; Paris, nouv. acq. lat. I544, fol. IO5 $^{\text {v; }}$ Rome, Santa Sabina, MS XIV.L, fol. I40 (mel); Tours, BM, I36, fol. I27; Vatican, BAV, reg. lat. I323, 8. BVI. I am grateful to Meghan Quinlan for sharing this information and her 2013 Oxford MSt thesis 'A melody lodged in the heart'.

7 Marshall, 'Gautier de Coinci imitateur de Guillem de Cabestanh', Romania, 98 (1977), 245-9; 'Imitation of form in Peire Cardenal', Romance Philology, 32 (1978), I8-48; 'The Descort of Albertet and its Old French imitation', Zeitschrift für romanische Philologie, 95 (1979), 290-306, and 'Pour l'étude des “contrafacta” dans la poésie des troubadours', Romania, IOI (I980), 289-335. See also Stefano Asperti, 'Contrafacta provenzali di modelli francesi', Messana, 8 (I991), 5-49.

${ }^{8}$ Gruber, Die Dialektik des Trobar: Untersuchungen zur Struktur und Entwicklung des okzitanischen und französischen Minnesangs des I2. Jahrhunderts, Beihefte zur Zeitschrift für romanische Philologie 194 (Tübingen, I983), p. 256.

9 Translations, unless otherwise noted, are my own.

10 '... it is very remarkable that the melody has been preserved with such uniformity as far as the melodic contour is concerned. Comparison of the versions as well as examination of textual and melodic characteristics make it rather clear that this uniformity is neither the consequence of a written tradition nor of strong metric features, but rather of a strong melodic structure', The Chansons of the Troubadours and Trouveres: A Study of the Melodies and their Relation to the Poems (Utrecht, 1972), p. 90. The melody has been edited a number of times, for example by Friedrich Gennrich, 'Internationale mittelalterliche Melodien', Zeitschrift für Musikwissenschaft, II (I928-9), 259-96; 32I-48 ('Can vei' 322-4), van der Werf, The Chansons of the Troubadours, pp. 90-5, and most recently in Tischler, Trouvère Lyrics with Melodies, III, no. 203. 2f.. All three editions indicate rhythm, although scholarship increasingly acknowledges that this may not be inferred reliably from the majority of thirteenth-century notation.

11 Bernart von Ventadorn: Seine Lieder mit Einleitung und Glossar (Halle, 1915). For the troubadour MS sigla, see The Troubadours: An Introduction, ed. Simon Gaunt and Sarah Kay (Cambridge, 1999), p. 304. 
12 Gaunt, 'Discourse desired: desire, subjectivity and mouvance in Can vei la lauzeta mover', in Desiring Discourse: The Literature of Love: Ovid through Chaucer, ed. James Paxson and Cynthia Gravlee (London, I998), pp. 89-IIO, text pp. I03f. Kaehne, by contrast, supports Appel's strophe order: 'Die Wahrung des offentsichtlichen Zusammenhangs zwischen Tornada und Str. 7 berechtigt zu der Annahme, daß auch die übrige Strophenfolge unverändert aus einer korrekten Vorlage übernommen wurde' ('The preservation of the evident relationship between the tornada and strophe 7 justifies the supposition that the rest of the strophic order was taken without change from a correct model'), Studien zur Dichtung Bernarts von Ventadorn, II, 237.

13 Cf. Gaunt, 'Discourse desired', p. I05, 'we might also consider the import of the fact that a less "courtly" version had more currency in the Middle Ages and that circulation in this form was no impediment to the song's popularity. Medieval tastes were clearly somewhat different from Appel's.'

${ }^{14}$ On his role in encouraging the students back to Paris from Orléans, see Thomas Payne, 'Aurelianis civitas: student unrest in medieval France and a conductus by Philip the Chancellor', Speculum, 75 (2000), 589-6I4 (p. 602).

15 Peter Dronke, 'The lyrical compositions of Philip the Chancellor', Studi Medievali, 28 (I987), 563-92 lists fifty-three attributed songs.

${ }^{16}$ A number of Philip's songs are contrafacta of secular songs: 'Veritas equitas' ( $A H$ 2I, I27), based on the anon. 'Gent me nais' (PC 56I, I24); 'Homo considera' ( $A H$ 24, I39), based on Peire Cardenal, 'Lo segle vei chamjar' (PC 335, 35); 'Mundus a Munditia' ( $A H$ 2I, 206), based on Marcabru, 'Dirai vos senes dubtansa' (PC 293, I8); 'Peter sancte dictus Lotharius' ( $A H$ 2I, 242), based on Gace Brulé, 'Douce dame, grés et graces vous rent' (RS 719), and 'Suspirat suspirans' ( $A H$ 2I, I63), based on Blondel, 'L'Amour dont sui espris' (RS I545). I am currently preparing an article on these engagements with vernacular song. 17 Philip also uses this technique elsewhere: Dreves, editor of the Analecta hymnica, attributes to Philip 'Homo natus ad laborem' ( $A H_{2}$ 2, I69), although no manuscript names him as the author. There is a musicological study of some of Philip's contrafacta, although this does not consider Philip's engagement with the text of his models; Robert Falck, 'Zwei Lieder Philipps des Kanzlers und ihre Vorbilder: Neue Aspekte musikalischer Entlehnung in der mittelalterlichen Monodie', Archiv für Musikwissenschaft, 24 (1967), 8I-98.

${ }_{18}$ Medieval Latin Lyric Vol. 3, ed. Penelope Rainey (Bryn Mawr, Pa, 1993), pp. 7I-5.

19 Compare Ovid, Amores I. 6, 7f., 'Ille [sc. Amor] per excubias custodum leniter ire|monstrat; inoffensos dirigit ille pedes' ('Love shows me how to walk quietly past the watchful guard, love who directs my unhindered feet'). The incipit addresses a 'ianitor', the word Philip uses for his doorman.

${ }^{20}$ Compare Andreas Capellanus' prohibition: 'Clericus non debet amoris operibus deservire, sed ... se Domino custodire, cuius creditur gestare militiam.' ('The cleric ought not to be a slave to love, but keep himself for the Lord, whose battle he is thought to fight.') De amore, ed. Graziano Ruffini (Milan, I980), p. 198 (\$ XIX. 3).

${ }^{21}$ Medieval Latin Lyric, p. 73.

22 Christopher Morris, The Discovery of the Individual I050-I200, Church History Outlines 5 (London, 1972), p. 75.

23 'Le Dit du Chancelier Philippe', in Les Dits de Henri d'Andeli, ed. Alain Corbellari, Classiques français du moyen-âge I46 (Paris, 2003), pp. 3I-4I. 'De toi mie ne se taisoit, 
/ Mais sovent biaus dis en faisoit / Et en romans \& en latin' (lines I43-5) ('He was never without praise for you, and often composed beautiful songs both in French and in Latin'). Corbellari wonders whether Andeli himself was the author of 'Le cuer se vait' (Les Dits, pp. I3of.), contradicting MS $X$, the only witness to name an author.

${ }_{24}$ For music and text, see Tischler, Trouvère Lyrics with Melodies, III, nos $203 \mathrm{f}$.

25 Frédéric Godefroy, Dictionnaire de l'ancienne langue française et de tous ses dialectes $d u$ IXe au XVe siècle, 9 vols (Paris, I88I) VI, 253.

${ }^{26}$ Köhler, 'Zur Struktur der altprovenzalischen Kanzone', Cahiers de civilisation médiéval, 7 (1964), 40-5I.

27 Johan Esteve, 'Planhen ploran ab desplazer' (PC 266, I0), Le Poesie del trovatore Johan Esteve, ed. Sergio Vatteroni, Biblioteca degli Studi Mediolatini e Volgari, Ns io (Pisa, I986), no. II, pp. II9-22.

${ }^{28}$ For a detailed examination of the play, see Elisabeth Schulze-Busacker, 'Le Théâtre occitan au XIVe siècle: Le Jeu de Sainte Agnès', in The Theatre in the Middle Ages, ed. Herman Braet et al., Mediaevalia Lovanensia, ser. I, I3 (Louvain, I985), pp. 130-93.

29 Le Jeu de Sainte Agnès: drame provençal du XIVe siècle, ed. Alfred Jeanroy (Paris, I93I).

30 See Tischler, Trouvere Lyrics, III, no. 203. There is also a musical appendix to Jeanroy's edition of Jeu de Sainte Agnès by Théodore Gérold.

31 On the idea of spectrality, see Sarah Kay, 'The "changeful pen": paradox, logical time, and poetic spectrality in the poems attributed to Chrétien de Troyes', in Zrinka Stahuljak, Virginie Greene, et al., Thinking through Chrétien de Troyes, Gallica I9 (Cambridge, 2010), pp. $15-40$ (p. 39).

32 For details, see n. 3 .

33 Schulze-Busacker, 'Le Théâtre occitan au XIVe siècle', pp. I92f. Jeu de Sainte Agnès, ed. Jeanroy, p. xx.

${ }_{34}$ Le Théatre religieux médiéval en langue d'oc, Bibliothèque de la Faculté de Philosophie et Lettres de l'Université de Liège 273 (Geneva, I998), p. 509.

35 Cronica Fratris Salimbene de Adam Ordinis Minorum, ed. Oswald Holder-Egger, MGH SS, 32 (Hanover, I905-13), p. I82. The other lyrics mentioned here are, respectively: $A H$ 2I, I2I, $A H$ 2I, I4, both probably by Philip. 'Virgo ...', not in $A H$, is no. 21902 in Ulysse Chevalier, Repertorium hymnologicum, 2 vols (Louvain, 1892-7), which attributes it to Philip. 'Centrum ...' is $A H$ 20, 88 also attributed to Philip.

36 Gianfranco Contini suggested that 'Quisquis' influenced Dante's dialogue between heart and eye in his trilingual poem 'Aï faus ris, qui tradis m'aves'. See Dante, Opere minori, ed. Domenico de Robertis and Contini, 2 vols (Milan, I984), I, 5Io.

37 Teodoro Llorente, Valencia, 2 vols (Barcelona, I889), II, I003f. n. 2.

38 José Ruiz de Lihory, La música en Valencia: diccionario biogràfico y crítico (Valencia, I903), pp. 84-9I (p. 86). I have regularized Ruiz de Lihory's transcription, expanding abbreviations and differentiating $\mathrm{u} / \mathrm{v}$.

39 Llorente, Valencia, II, I006-8. At the time of Llorente's research the manuscript was in the hands of one Salvadro Sastre (p. I006 n. 3).

40 'La cançó provençal en la literatura catalana', in Miscel-lània Prat de la Riba, 2 vols (Barcelona, 1917-23), II (I923), pp. 445f., referring to Henri Mérimée, L’Art dramatique à Valencia depuis les origines jusqu'au commencement du XVIIe siècle, Bibliothèque méridionale, NS I6 (Toulouse, I9I3). 